doi: $10.19090 / \mathrm{i} .2018 .29 .63-77$

UDC: 339.1 "17“"

ISTRAŽIVANJA

JOURNAL OF HISTORICAL RESEARCHES

29 (2018)
ORIGINAL SCIENTIFIC PAPER

Received: 7 July 2018

Accepted: 31 August 2018

\author{
BORO BRONZA \\ University of Banja Luka \\ Faculty of Philosophy, Department of History \\ boro.bronza@unibl.rs
}

\title{
PREPARATIONS OF THE AUSTRIAN EXPEDITION TOWARDS INDIA 1775-1776
}

\begin{abstract}
During the second half of the 18th century Austria's trade policy sought to restore ties to India and other parts of Asia that had successfully existed during the period of the Ostend Company (1722-1731). In this respect, the increasingly successful activity of the British East India Company was an example for the Vienna government in indicating of which lucrative possibilities lay in the proper development of trade in the east. Austria soon decided to try to organize trade expeditions to India itself and the British experience was of primary importance to it. An indispensable link for the launch of such ventures was the opportunity for the representatives of the Austrian diplomatic network to meet directly with individuals from the group of traders who had already had extensive experience in trade with India. This was exactly the case in London in 1774, when the Austrian Ambassador Ludovico Luigi Carlo Maria di Barbiano di Belgiojoso met one of the most famous European entrepreneurs of the second half of the 18th century, William Bolts. It was the beginning of a new great Austrian adventure in Asia and at the same time an attempt to radically redefine the essential nature of the Habsburg position and philosophy. Immediately after the Austrian diplomatic network came into contact with Bolts, the sophisticated preparations of the expedition began, before the final take off in 1776.
\end{abstract}

Keywords: Austria, India, Maria Theresa, Joseph II, William Bolts.

$\mathrm{D}$ uring the $18^{\text {th }}$ century the Habsburg Monarchy slowly, agonizingly, but ultimately uncompromisingly converted to Austria. The aspects of centralization in the frame of state institutions whose development was usually implied in the case of some other European state equivalents and opponents, mostly determined as national states, remained largely unknown to the concept of Viennese structures until the very collapse of the entire Habsburg system in 1918. Nevertheless, the second half of $18^{\text {th }}$ century was the period when, through intense reforms, many of the dysfunctional Habsburgs milieus evolved into a coherent set with more pronounced functionality. Among others, the change was indicated by the positioning on the north western European coast, right after the outcome of the War of Spanish Succession (1701-1714). Thanks to the possession of 
Antwerp, Oostende and other coastal cities in Southern Netherlands, the perspectives of participation in the Western European trading conglomerate, comprising primarily Great Britain, the Netherlands and France, opened up for Austria at the very height of economic dominance of those nations in the planetary framework. In this way, Austria was actually given the opportunity to become a Western European state much more than ever before.

An additional dimension in such a transformation should have been represented by numerous Spanish advisers who were brought to the courtyard in Vienna by Emperor Carlo VI (1711-1740) after his episode in Catalonia (1705-1711) and unsuccessful attempts to gain the Spanish crown. Already a couple of centuries-old Spanish colonial experience was supposed to help Austria to organize its own colonial and trade policy more efficiently. In this context, Spanish consultants should have had a key role in projects aimed at establishing trade relations between Austria and very remote areas such as India and China. ${ }^{1}$

Since the end of the Thirty Years' War in 1648 the mouth of the River Scheldt into the North Sea was under the firm control of the (northern) Dutch. In this way, they completely closed the possibility of Antwerp and Southern (Spanish) Netherlands to use the port, which during most of the $16^{\text {th }}$ century was without any doubt the spot of most important and busiest world maritime and commercial crossroads and which made Antwerp the most important planetary economic centre. ${ }^{2}$

Due to the inability to use Antwerp, the Austrian authorities directed by Spanish advisers decided to choose Ostend (Oostende), a small town west of Bruges, to the northwest of Gent and Brussels, for the centre of its maritime efforts on the coast of Flanders, which at that time actually represented the only location with an acceptable harbour on the entire coast of the Austrian Netherlands. Although the attempt with Ostend was initially an improvisation, it was quickly proven that this place was an excellent choice since as early as 1715 Austrian merchant ships from this Flanders port were increasingly sailing towards Arabia, India and China. ${ }^{3}$

The Emperor put the Ostend Company under the full patronage of the state in December 1722 and enabled it to have a huge starting capital of six million guilders, with the capital being divided into 6,000 shares, each of which had a value of 1,000 guilders. Shares were put up for sale at the stock exchange in Antwerp on 11 August 1723. They were purchased mostly by local retailers from Antwerp and Gent so that in the end a group of 54 largest investors from Antwerp itself had as many as 3,037 shares or more than 50 percent of the total emissions. The election of the company director was done in accordance with this and they were largely recruited by the key local retailers. Jacques De Pret, Louis-François de Coninck and Pietro Proli represented Antwerp, while Jacques Maelcamp, Paulo De Kimp and Jacques Baut represented Ghent, and the Irish trader Thomas Ray figured as a representative

\footnotetext{
${ }^{1}$ Faber 1995: 51.

${ }^{2}$ Despite many Austrian attempts throughout the $18^{\text {th }}$ century, the Scheldt was not open to maritime traffic. The Netherlands owned a monopoly on the trade at the mouth of the Scheldt until 1863. This relationship directed by the Dutch that resulted in Antwerp's few centuries of deliberate poverty had intense reflections on the relations between the Netherlands and Belgium, which in the war of 1830-1839 managed to diverge from the Netherlands and become an independent state. Israel 1995: 1013.

${ }^{3}$ Keay 1991: 247.
} 
of Ostend. ${ }^{4}$ One of the main shareholders was Leopold Philip, Duke of Arenberg. Although the ships sailed from Ostend, the company's headquarters were in Antwerp. ${ }^{5}$

The Austrian company thus became a surprisingly significant competition for British and Dutch merchants. Under pressure from Great Britain and the Netherlands, the Company's work was suspended for seven years on 31 May 1727. Soon it turned out that this was not enough for the traditional naval forces, so Charles VI, in a treaty with Great Britain of 16 March 1731 agreed to completely abolish the Ostend Company, with the permission to maintain a minimum trade with India (a possibility to send only two ship for India annually). Thus, the Habsburg ruler destroyed the most profitable Austrian trading company throughout the whole of the $18^{\text {th }}$ century. The political decision related to an attempt to obtain the recognition of the Pragmatic Sanction, which was the reason for its liquidation only nine years later, was no longer significant because of the outbreak of the War of Austrian Succession (1740-1748). ${ }^{6}$

In the coming decades came a complete collapse of Austrian trade towards the southern and eastern parts of Asia. The Austrian concentration on the events in Europe, and in particular the struggle with Prussia to overcome issues related to the organization of German affairs, completely dominated Austrian politics during the first three decades after the death of Charles VI in 1740. It was only in the late 1760s that there was more diversification in Austrian foreign policy, which was largely a reflection of the growing influence of Joseph II, the crown prince, i.e. from 1765 a co-ruler of his mother, Empress Maria Theresa. Austrian diplomacy around that time began a new phase of its institutional development manifested by the creation of sophisticated plans for new aspects of expansion towards the southeast.

An example of the success of Britain, as well as other West European maritime trading powers, in the first place of the Republic of the Seven United Provinces of the Netherlands (Republiek der Zeven Verenigde Nederlanden) and France, was a propellant for the creation of much wider projects in both geographical and economic contexts. Undoubtedly, implied by the results of its relatively short existence (1751-1765), the Emden East India Trading Company (Emder Ostasiatische Handelskompanie), owned by the Prussian rival, ${ }^{7}$ the Austrian government gathered around Prince Kaunitz (Wenzel Anton von Kaunitz-Rietberg, 1711-1794) was increasingly open to the creation of a diplomatic and economic policy with intercontinental dimensions.

One of the main points in the growingly sophisticated system of Habsburg diplomacy was the embassy in London. Its significance grew in line with the growing importance of Great Britain in the world. Since 10 March 1770 the head of the Austrian diplomatic mission in London was Ambassador Ludovico Luigi Carlo Maria di Barbiano e Belgiojoso (17281801). The Count of Belgiojoso was a descendant of an Italian aristocratic family, who had their headquarters in the same town in the south of Milan. ${ }^{8}$ His father and grandfather had

\footnotetext{
${ }^{4}$ Baguet 2015: 51-52.

${ }^{5}$ Michielsen 1937: 129.

${ }^{6}$ Nagel 2007: 57.

${ }^{7}$ Eberstein 2007: 23 .

${ }^{8}$ Today, Belgioioso is actually one of the southern suburbs of Milan. The family name is most commonly written as Belgiojoso and the name of the place Belgioioso originates from the family name. However, there are many
} 
already performed very important functions in the system of Austrian administration and diplomacy during the past decades, which was in line with the fact that the Duchy of Milan from the 1713 (Utrecht peace) was also under the direct administration of the Habsburg Monarchy. From 1764 to 1769 Belgiojoso served as an Austrian ambassador to Sweden and after good results in the diplomatic field, with the satisfaction and personal recommendation of Empress Maria Theresa, he was transferred to the prestigious London position.

In the context of Austrian diplomatic attempts to open as many channels as possible to stimulate trade to various parts of the world, and especially to Asia, it was Belgiojoso who was fortunate to meet with William Bolts (1739-1808), who would prove to be an absolute crucial person in the development of Austrian trade towards the east in the course of the next fifteen years. In principle, this was a very logical outcome, primarily due to the fact that London was then an absolute centre of world trade and economy in general. The meeting with Bolts was considered as a direct hit for the Austrian ambassador. Given the current scrutiny of Vienna, however, it should not be forgotten that Bolts sought to meet him, and not vice versa. ${ }^{9}$ That was actually pretty much expected, because Bolts himself at that moment desperately needed sponsors and patrons to achieve his own grandiose plans.

William Bolts ${ }^{10}$ was born in Amsterdam in 1739 as a descendant of the Germans from Palatinate (Pfalz). ${ }^{11}$ During the 1750 s he worked in diamond trade in Lisbon. This experience significantly helped him to position himself well in diamond jobs later in India, where he arrived in 1759 as an employee of the British East India Company. From the very beginning of his stay in Bengal, in Kolkata (formerly Calcutta), Bolts achieved excellent results, among other things thanks to his exceptional language talent. In addition to speaking fluently five European languages, he quickly learned Bengali. Later on, Bolts moved more westward to the interior of the northern part of the Indian subcontinent and mostly operated in the Bundelkhand area, especially in Varanasi (formerly Benares), where he increasingly controlled the diamond trade. ${ }^{12}$

The ability to get involved in the fabulous financial transactions that were often conducted illegally in the framework of the East India Company enabled Bolts to quickly acquire quite a fortune. Consequently, he became a disruptive factor for the higher

contrary examples. Count Belgiojoso often signed himself as Belgijoso in his reports, which caused additional confusion, especially when he later acted in the area of today's Belgium, 1783-1787.

${ }^{9}$ The confusion is somewhat still aroused by the views expressed in older works, according to which Belgiojoso first contacted Bolts. As such they are particularly reflected in Pollack-Parnau 1927: 18. The mistakes of this type are indicated already earlier - Aretin 1959: 364.

${ }^{10}$ This form of the name has become dominantly recognizable in historiography precisely because of its British affiliation during a significant part of Bolts' business career. Due to German origin, Wilhelm Bolts would be more precise. Often there is a French form - Guillaume Bolts, as in his letters this merchant and adventurer was largely signed. In some older examples of German literature his surname is also listed in the more classic German form - Bolz.

${ }^{11}$ According to some sources he was born in 1738 and according to others earlier in 1735. However, in 1739, the prevalence of information was based on the Amsterdam register of baptisms, where he was entered on 21 February 1739. It is possible that his mother was English. His father was definitely German. Gough - King 2005: 10.

${ }^{12}$ Hallward 1920: 3-5. This book by Norman Leslie Hallward is the most complete presentation of Bolts' career in the period he spent in India. Unfortunately Bolts' projects and entrepreneurship in the coming decades are only sporadically touched upon in this work, whose value is further underlined by the fact that in 2015 Cambridge University Press published a reprint of the original 1920 edition. 
positioned administrators of the Company in India, so the conflict with them was almost inevitable. According to Bolts, Harry Verelst (1734-1785), the commander of Fort William in Kolkata, 1767-1769, was particularly hostile towards him and problematic regarding the illegal dealing in the frame of East India Company, but at the same time he was the highest ranking company administrator in India. ${ }^{13}$ Problems for Bolts began in 1766 and they culminated during 1768 and 1769, when he was arrested by the company's representative and put on a ship to England. Immediately after the company ship "Valentine" sailed into the port of Plymouth on 30 April 1769 Bolts launched a lawsuit against the company's representative. Now settled on the British ground, he was not a convict anymore, i.e. the laws applied by the East India Company itself referring to his deprivation of liberty were valid only in the territory of India where they actually had administrative authority. ${ }^{14}$

Over the coming years, Bolts launched a massive propaganda campaign against the East India Company seeking to discredit as much as possible the methods of their work in India. In particular, he pointed to the widespread corruption and illegal trade. Apart from the personal desire for revenge against the leading people of the Company, the reasons for such a performance by Bolts laid also in the fact that a large amount of his wealth remained in Bengal, mostly in shares and real estate. He primarily cultivated the plan that he would somehow be able to return to India and that he would be able to re-occupy all those segments of his capital, which he earned primarily from 1760 to 1766, when he worked directly for the Company in Bengal and Bundelkhand.

Because of his problems with the Company in 1772 Bolts published a comprehensive study on the system of operation of the East India Company in the area of Bengal and other Indian regions under the title Considerations on India affairs: particularly respecting the present state of Bengal and its dependencies, ${ }^{15}$ in which he revealed a whole range of machinations in the work of then definitely the most profitable British and even world company. The book quickly became a bestseller and William Bolts earned a fair glory for success, but not the desired wealth and all the dimensions of the vengeance he desperately wanted. The British public, thanks to Bolts, was much more concerned with corruption and criminality within the East India Company in India, but the company's economic and

\footnotetext{
${ }^{13}$ In 1767 Verelst replaced Robert Clive as the commander of the Fort William fortress, who in 1757 after winning the Battle of Palashia (formerly Plassey) actually secured the dominance of the East India Company in Bengal. He performed the duty from May 1767 to December 1769. Later, in 1771, Verelst became the director of the East India Company. The Gentleman's Magazine, 1785, ii., 920.

${ }^{14}$ Hallward 1920: 45-99.

${ }^{15}$ The first part of the book was published on 412 pages in 1772: William Bolts, Considerations on India affairs: particularly respecting the present state of Bengal and its dependencies: to which is Prefixed, a Map of Those Countries, Chiefly from Actual Surveys, Band 1, Printed for J. Almon, P. Elmsly, and Brotherton and Sewell, London 1772. The second part was published on over 600 pages in 1775 and was primarily Bolts' triumph because Verelst was convicted in the meantime: William Bolts, Considerations on India affairs, Part II. Containing a complete Vindication of the Author from the Malicious and Groundless Charges of Mr Verelest with a just Exposure of the Fatal Ignorance and Injustice of the late Courts of East India Directors in London and of the Oppressions and Iniquities of their late Governing servants in Bengal, Printed for J. Dodsley, Pallmall; G. Robson, New Bond street; J. Almon, Piccadilly; Jefferies and Faden, Charing-Cross; P. Elmsly, in the Strand; W. Owen, Fleet-street; T. Evans, Paternoster row; Brotherton and Sewell, in Cornhill; and Richardson and Urquhart, under the Royal Exchange, London 1775.
} 
political conglomerate was so powerful and so needed both by the British Crown and British trading circuits that there was no chance for the Company to be liquidated and neither its direct takeover by the Crown was in sight, ${ }^{16}$ which Bolts actually wanted to happen. ${ }^{17}$

In any case, the success of the 1772 publication meant that prospects of Bolts' possibility to return to India within the framework of British institutions was sealed. However, at the same time, Bolts made a breakthrough at the European level for now he was known as an expert in organizing trade issues with India. Consequently, the former British merchant expected an engagement by another European power that was striving to develop trade with Asia. Even more than that, Bolts sought to further develop his newlygained fame and unquestioned expertise in Indian trade as soon as he entered into an arrangement with another European country. Carefully observing the evolution of the situation in Europe and the trends that were largely dictated to the relations that countries and regions had with Great Britain, Bolts decided to try to join Austrian diplomacy in order to possibly agree the details of the project of developing trade towards India with the Vienna court.

Bolts' decision to join Austria was based on several factors. Since he had excellent connections across Europe, because of his origins and business relations with the territories of Germany, the Netherlands, Great Britain and Portugal, he was in a position to assess the geographical capabilities of Austria and its imperial conglomerate to develop trade with India. Bolts' connections were particularly strong with traders operating in the Netherlands and the Austrian Netherlands. However, he was aware of the restrictions that had been applied on Austria for decades regarding the trade from Antwerp or Ostend. That is why his idea for the development of trade from the perspective of Austria was focused on Austrian properties in the Mediterranean. In that sense, Port of Trieste was of particular importance and he conceived it as a central loading place for the entire Habsburg Monarchy. In addition, he was aware of the potential of Livorno, the main Tuscan port, which had a special position due to the fact that Tuscany had been in the Habsburg estate since 1737 as a secundogeniture.

Since 1765 Tuscany was governed by Leopold (1747-1792), the younger son of Empress Maria Theresa and brother to the heir to the throne Joseph II. His reign in Tuscany (1765-1790) was rather liberal and open to economic experiments that could improve the economic position of the province, which in the past few centuries had continuously deteriorated in relation to the position that it had had during the Renaissance period. For Bolts' plans the added advantage of Livorno (called Leghorn in most British sources of the

\footnotetext{
${ }^{16}$ This would actually happen in the second half of the $19^{\text {th }}$ century and the East India Company would finally be extinguished in 1874. Williams 2015: 182.

${ }^{17}$ After the publicaton of Bolts' book, Harry Verelst hastened to publish his answer and in 1772 his book appeared - Harry Verelst, A View of the Rise, Progress, and Present State of the English Government in Bengal: Including a Reply to the Misrepresentations of Mr. Bolts, and Other Writers, Printed for J. Nourse, Bookseller of His Majesty in the Strand; Brotherton and Sewell, in Cornhill; G. Robinson in Paternoster row; and T. Evans in the King-street, Covent-garden, London 1772. In this book Verelst managed to somewhat relativize some of Bolts' allegations and to present his counter-claims. However, this did not prevent the initiation of the trial which resulted in a verdict in December 1774 that Verelst had to pay a sum of 5,000 pounds due to the wrongfulness of many cases, including also Bolts' arrest in Bengal in 1768. The Gentleman 's Magazine, 1785, ii., 920.
} 
$18^{\text {th }}$ century) over Trieste was reflected in the fact that sailing from Livorno through the western part of the Mediterranean was much safer than the trip from Trieste, as the maritime route from Livorno to Gibraltar was not so exposed to the attacks of Berber pirates from North Africa. ${ }^{18}$

Other reasons that Bolts put his efforts exclusively to the Austrian option lay in the fact that the Habsburgs ruled the Austrian Netherlands, the space where most of the potential investors for his planned trade organization with India actually lived, with some of the trading families from Antwerp and Ostend being involved in the organization of trade with Asia as early as the era of the Ostend Company. Many high-ranking Austrian officials had traditionally good connections with them and Bolts thought that the best way would be to exploit the Austro-Belgian milieu in that way. Connections and positions that the Chancellor Kaunitz himself had on the territory of the Austrian Netherlands were of particular importance ${ }^{19}$ and the similar case was with influential families of Cobenzl $^{20}$ and Starhemberg as well. ${ }^{21}$

In the end, Bolts saw the reason to opt with Austria because of the European geopolitical constellation of that time. The fact that Great Britain was in a position of certain diplomatic isolation after its great victory in the Seven Years' War implied that almost all European countries were in a way stunned and scared by the newly emerging British domination. Already during the first meeting with the Austrian ambassador in London, ${ }^{22}$ Bolts surprised his interlocutor with the richness of his ideas and in his exposed plans for the development of trade with Asia there were not only expeditions to India, but also towards China. After his first talk with Bolts, Ambassador Belgiojoso wrote to Vienna on 1 November 1774. ${ }^{23}$ Immediately after the arrival of Belgiojoso's report, Chancellor Kaunitz developed a very intense discussion of Bolts' proposal in Vienna and ordered various departments to analyze it in detail, primarily the order was sent to the President of the

\footnotetext{
${ }^{18}$ Frendo 1998: 143-151.

${ }^{19}$ From 1745 to 1748 Kaunitz served as an Austrian administrator and temporarily as a de facto governor in the Austrian Netherlands.

${ }^{20}$ Count Johann Karl Philipp von Cobenzl (1712-1770) held the position of the Plenipotentiary Minister for the Austrian Netherlands 1753-1770. It was, de facto, the post of prime minister within the administration headed by Governor - Prince Karl Alexander von Lothringen und Bar (1712-1780), the younger brother of Maria Theresa's husband, Franz Stephan, the Emperor of the Holy Roman Empire (1745-1765) and at the same time the husband of an Archduchess Maria Anne (1718-1744), the younger sister of Empress Maria Theresa. The son of Charles Philippe von Cobenzl, Count Johann Ludwig von Cobenzl (1753-1809), was one of the most important Austrian diplomats between 1772 and 1800. He held the position of the ambassador in Russia continuously between 1779 and 1797. From 1800 to 1805 he was the vice-chancellor and minister of foreign affairs of Austria.

${ }^{21}$ Prince Johann Georg Adam von Starhemberg (1724-1807) succeeded the count Karl Philippe von Cobenzel as the empowered minister for the area of the Austrian Netherlands and served as the key Austrian executive administrator in the present-day Belgium and Luxembourg areas between 1770 and 1783.

${ }^{22}$ N. L. Halward, who did not use Austrian archive material at all, mistakenly considered that Bolts himself organized his journey to Vienna in early 1774 and that he had already met with Maria Theresa at that time. Hallward 1920: 151.

${ }^{23}$ Österreichisches Staatsarchiv, Abteilung Haus-, Hof- und Staatsarchiv (further: HHStA), Ostindische Kompanien (1661-1792), Triest-Antwerpen, Kart. 4: Diplomatische Korrespondenz der Staatskanzlei mit der Kompanie (1774-1786), Fasz. Diplomatische Korrespondenzen der Staatskanzlei 1774-1776, Konv. 1 (1-8), Fol. 4.
} 
Chamber of Commerce, Count Leopold von Kollowrath-Krakowski (1726-1809). ${ }^{24}$

The next report about the meeting with Bolts by ambassador Belgiojoso was sent on 27 December 1774. ${ }^{25}$ A new round of interest awakened in Vienna and the court excitedly developed thoughts about the perspectives that were implied by Bolts' promises. In the first months of 1775 there was a new wave of systematization. On 6 March Belgiojoso sent to Vienna a detailed proposal from Bolts regarding the project entitled Expedition towards East India (Expedition nach Ostindien). ${ }^{26}$ In his letters the Austrian ambassador testified about Bolts as a well-known celebrity in London, as well as an unparalleled connoisseur of opportunity in India. Obviously, Bolts was able to present himself as a much more important factor in London's circles than he really was. In any case, the concept proposed by the former employer of the East India Company concerning the organization of trade in India and China from Trieste was a surprise for circles in Vienna because they themselves had never thought about a possible use of their own Adriatic port ${ }^{27}$ for such ventures, although Trieste was increasingly gaining importance in the context of the development of its pier during the $18^{\text {th }}$ century. ${ }^{28}$

Not everyone in Vienna was thrilled with Bolts' ideas. Joseph II expressed a certain suspicion regarding the project, which, in his view, could have cost Austria a lot and the possible profit was indeed very questionable. ${ }^{29}$ His dilemma was shared by Count Karl von Zinzendorf (1739-1813), court adviser and one of the key economic theorists of the Habsburg Monarchy. After the detailed Bolts' study arrived to Vienna in March, Maria Theresa ordered the court office and the Chamber of Commerce to fully analyze the possibilities that came from the brave merchant's idea. The government in Vienna was aware that it had a very promising option ahead of itself and that it could not afford the opportunity for such an idea to slip into the hands of the opponents, who was logically at that time primarily Prussia. In order to prevent any possible competition, the Habsburg government sent an urgent letter to Belgiojoso in London requesting that Bolts should be directed to Vienna immediately. For the sake of the strict secrecy of the entire project, it was recommended that during the travel from London to Vienna he should be dressed and represented as a Portuguese trader, which was not a problem for Bolts because he was fluent

${ }^{24}$ HHStA, Ostindische Kompanien (1661-1792), Triest-Antwerpen, Kart. 3: Ostindische Kompanie Triest Antwerpen (1774-1788), Fasz. Korrespondenz der Staatskanzlei mit Hofstellen 1774-1776, 1778-80, Konv. 1 (1-2), Fol. 1.

25 HHStA, Ostindische Kompanien (1661-1792), Triest-Antwerpen, Kart. 1: Ostindische Kompanie Triest Antwerpen 1661, 1766-1789, Fasz. 1, Fol. 4-5.

${ }^{26}$ HHStA, Ostindische Kompanien (1661-1792), Triest-Antwerpen, Kart. 1: Ostindische Kompanie Triest Antwerpen 1661, 1766-1789, Fasz. 1, Fol. 6-7.

${ }^{27}$ It was Habsburg property since 1382. Faber 1995: 37.

${ }^{28}$ Markov 1961: 3-28; Beer 1899: 1-204; Erceg 1966: 300-308; Gasser 1954: 120-130.

${ }^{29}$ Such attitude of Joseph II will remain the rule in the context of the relationship with the project of William Bolts in all subsequent years, when the expeditions to India really took place and when the Austrian East India companies achieved some results. In all matters, he always required the submission of financial guarantees by external factors or investors and he explicitly refused to give Vienna money to finance expeditions or companies. Such reactions were also a response to Bolts' demands of 11 July 1782, when it seemed most likely that the newly formed company would achieve tremendous results in trade with Asia. HHStA, Ostindische Kompanien (1661-1792), Triest-Antwerpen, Kart. 2: Ostindische Kompanie Triest Antwerpen (1774-1787), Fasz. Vorträge 1781-84, Fol. 42, 49-50. 
in the Portuguese language. ${ }^{30}$

In early May 1775 Bolts arrived to Vienna for preliminary talks about the implementation of his project. The first meeting, held on 13 May in Vienna, with a delegation comprising court advisors Kollowrath, Bender and Franz Anton von Raab (17221783), greatly helped the former representative of the East India Company to leave a very favourable impression on his interlocutors, who labelled him as a person who "by his external appearance, the freedom of his behaviour and his own views" 31 represented something unusual. In order to gain the favour of the court in Vienna, he initially appeared very optimistical and in his "secret brief of 14 May 14"32 immediately claimed that his intention was "to supply two ships to East India that year and to direct his journey to Malabar, where all nations can trade freely." 33

In the context of indicating the types of goods he intended to trade in India and the area of the Indian ocean, Bolts made a meaningful emphasis on the "products from hereditary lands," 34 which meant products available from the then Habsburg hereditary countries Lower and Upper Austria, Tyrol, Styria, Carinthia, Carniola, the Czech Republic, Hungary and others. Such orientation was probably most interesting in court circles in Vienna because they were almost all mostly fairly involved in the trade of goods related to the local geographical areas. In this sense, Bolts specifically sought iron, steel, rifles, cannons, glass and glassware, but silver and silverware too. On the other hand, from the territory of the Austrian Netherlands Bolts requested various fabrics, sail material and ship ropes. ${ }^{35}$

Basically, Bolts was personally most interested in trading with Flemish products because he expected the largest influx of investors for his planned expedition from the Austrian Netherlands and especially from Antwerp. In addition, he knew that the trade with arms was very lucrative in the area he wanted to visit, especially in the situation when almost the whole Indian subcontinent was politically extremely unstable due to the aggressive action of the British East India Company. ${ }^{36}$ However, he did not show his intention to reveal his plans for potential business partners in Vienna. In addition, he tried as much as possible to hide the real information about his assets, pointing out that he had left a fortune of 60,000 British pounds in Bengal. ${ }^{37}$ The only partner, i.e. the assistant who was almost constantly

${ }^{30}$ HHStA, Ostindische Kompanien (1661-1792), Triest-Antwerpen, Kart. 4: Diplomatische Korrespondenz der Staatskanzlei mit der Kompanie (1774-1786), Fasz. Diplomatische Korrespondenzen der Staatskanzlei 1774 1776, Konv. Ostindische Compagnie Correspondenz mit auswärtigen Höfen und Gubernien 1775, Fol. 8-9.

31 „...̈̈usserliches Wesen, die Freimütigkeit seines Betragens, seine Einsicht...“, HHStA, Ostindische Kompanien (1661-1792), Triest-Antwerpen, Kart. 1: Ostindische Kompanie Triest Antwerpen 1661, 1766-1789, Fasz. 1, Fol. 10.

${ }^{32}$ „In geheimen Vortrag“, HHStA, Ostindische Kompanien (1661-1792), Triest-Antwerpen, Kart. 1: Ostindische Kompanie Triest Antwerpen 1661, 1766-1789, Fasz. 1, Fol. 8.

33 „Will er noch dieses Jahr zwey Schiffe nach Ostindien ausrüsten und seine Reise an die Küste von Malabar richten, wo alle Nationen frey handlen können." HHStA, Ostindische Kompanien (1661-1792), TriestAntwerpen, Kart. 1: Ostindische Kompanie Triest Antwerpen 1661, 1766-1789, Fasz. 1, Fol. 9-10.

${ }^{34}$, ,...von erbländischen Productis“, Ibid.

${ }^{35}$ Ibid.

${ }^{36}$ Temple 1917: 278.

37 Considering inflation of British pound, this value would amount to nearly 3.5 million today. 
with him on display was a certain François Ryan. ${ }^{38}$

After Bolts' stay in Vienna and his presentation of a rounded plan on the development of trade with Asia, the Austrian government, primarily through its diplomatic network, rushed to urgently finalize the options arising from Bolts' idea. As a skilled trader primarily sought an imperial sanction, that is, a charter or a patent ("Oktroi"), which would allow him to position himself monopolistically on behalf of Austria in India and in the wider Indian Ocean, the reaction of Vienna was to be really quick. The Austrian diplomatic network collected additional information, among others, through its ambassador to the Netherlands, Baron Franz von Reischach (1732-1808). In this regard, the communication that Prince Kollowrath had with the ambassador in The Hague in the summer of 1775 was of particular importance. $^{39}$

Baron Peter Philipp von Herbert-Rathkeal (1735-1802) played a significant role in collecting data about Bolts and possibilities for the development of East India trade within the parameters proposed in Vienna. During the summer of 1775 he served as the court adviser within the framework of the Austrian administration in Brussels. ${ }^{40}$ Herbert-Rathkeal was given the task of closely monitoring the development of the situation around the expedition's investors in the Austrian Netherlands and to follow Bolts until his very departure to the expedition in $1776 .{ }^{41}$ Chancellor Kaunitz, who had been in Luxembourg on several occasions in 1775, provided further useful information about the situation in Belgium and Bolts' position with the help of Prince Johann von Starhemberg from Brussels. $^{42}$

After Maria Theresa sublimated all the information she received, she decided to sign the required charter for Bolts despite the fact that in Vienna they were somewhat aware of the complexity of Bolts' position, primarily in terms of his continuing dispute with the British East India Company and problems that may arise for Austria from possible complications with the British institutions. The Empress considered that a significant benefit could have been derived from the East Indian enterprise. As early as 15 May Bolts

\footnotetext{
http://www.historicalstatistics.org/Currencyconverter.html (accessed 14 April 2018, 21:37)

${ }^{38}$ Houtman-De Smedt 1999: 229.

39 HHStA, Ostindische Kompanien (1661-1792), Triest-Antwerpen, Kart. 3: Ostindische Kompanie Triest Antwerpen (1774-1788), Fasz. Korrespondenz der Staatskanzlei mit Hofstellen 1774-1776, 1778-80, Konv. 1 (1-2), Fol. 3.

${ }^{40}$ Peter Philipp von Herbert-Rathkeal was a descendant of an immigrant Irish family who left Ireland after the Revolution of 1688 and, like many Catholic emigrants from Britain, was under the banner of the Habsburg circles during the $18^{\text {th }}$ century. In the context of scholarship Peter Philipp and his younger brother Thomas were personally supported by Maria Theresa. In the period from 1750 to 1760 Peter Philipp was a member of the Jesuit Order and after that he made a career in the Austrian administration. From 1779 to 1802 he served as an Austrian internuncio in Istanbul. Irish origins often gave him strong ties with British trading circles and his career in Brussels connected him with Belgian and Dutch traders, which was of great benefit to the Habsburgs in 1775 and later when he, as internuncio, would be for more than two decades one of the central points in coordination of the complete Austrian policy towards Asia. Bronza 2013: 329-338.

${ }^{41}$ HHStA, Ostindische Kompanien (1661-1792), Triest-Antwerpen, Kart. 1: Ostindische Kompanie Triest Antwerpen 1661, 1766-1789, Fasz. 1, Fol. 34.

${ }^{42}$ HHStA, Ostindische Kompanien (1661-1792), Triest-Antwerpen, Kart. 3: Ostindische Kompanie Triest Antwerpen (1774-1788), Fasz. Korrespondenz der Staatskanzlei mit Hofstellen 1774-1776, 1778-80, Konv. 1 (1-2), Fol. 12-25.
} 
took the oath as a subject of the Habsburg Monarchy and was officially allowed to receive a charter or a patent. The Empress finally signed it on 5 June. The Charter encompassed 18 articles and for the standards of the $18^{\text {th }}$ century was basically pretty poor and limited in the context of the precise definition regarding Vienna's obligations and the scope of future authority of William Bolts. ${ }^{43}$

By signing the patent for Bolts, Austria launched an institutional action that would promptly, in September 1775, lead to the formation of the Austrian East India Company, that is the "Imperial Asian Company Trieste and Antwerp" ("Société impériale asiatique de Trieste et Anvers"), immediately after the business merging of Bolts with investors from Antwerp ${ }^{44}$ led by banker Charles Proli (1723-1786), whose father was one of the directors of an old Ostend company from the first half of the $18^{\text {th }}$ century. ${ }^{45}$

Relations between Bolts and Proli were of particular importance for the fate of the prepared expeditions, but from the very beginning they proved to be quite heavy. In essence, Proli was the main investor and wanted to have a crucial share in the decisions that dealt with the main expedition guidelines, while Bolts wished that he had complete control in that respect. Thus, Proli tried, without Bolts' support, to act completely independently in his contacts with Vienna, which was reflected in his many letters to Prince Kaunitz and other leading Austrian figures. In his report to Vienna on 2 November 1775 he emphasized the history of the involvement of his family in Austrian affairs since the time of the Ostend Company, which was intended to further show how he should be the key person in the context of the perception of the expedition for the Austrians. ${ }^{46}$ During 1776 he was particularly concentrated on the development of his relations with the Tuscan duke Leopold as it was certain that Livorno would play a major role as the main port of the expedition. ${ }^{47}$

Already during the autumn of 1775 Bolts and his associate Ryan continued with the elaborations of their trading plans in Vienna. Thus, on 30 October it was announced that Bolts' previous links, established in Lisbon some 20 years earlier, would play an important role in the context of logistics related to the expedition towards India. ${ }^{48}$ Immediately after that, Bolts contacted the Austrian Ambassador to Lisbon, baron Adam von Lebzeltern $(1735-1818){ }^{49}$

\footnotetext{
${ }^{43}$ Bolts 1787: 44-49.

${ }^{44}$ On 25 January 1776 Herbert-Rathkeal explained from the Austrian Netherlands in detail to Marshal Haddik and other interested leaders in Vienna how Bolts systematically managed to gain confidence „des bonnes maisons d'Anvers", HHStA, Ostindische Kompanien (1661-1792), Triest-Antwerpen, Kart. 3: Ostindische Kompanie Triest Antwerpen (1774-1788), Fasz. Korrespondenz der Staatskanzlei mit Hofstellen 1774-1776, 1778-80, Konv. 1 (1-2), Fol. 41-43.

${ }^{45}$ Houtman-De Smedt 1983: 12.

${ }^{46}$ HHStA, Ostindische Kompanien (1661-1792), Triest-Antwerpen, Kart. 4: Diplomatische Korrespondenz der Staatskanzlei mit der Kompanie (1774-1786), Fasz. Diplomatische Korrespondenzen der Staatskanzlei 17741776, Konv. Ostindische Compagnie Correspondenz mit auswärtigen Höfen und Gubernien 1775, Fol. $28-31$.

${ }^{47}$ HHStA, Ostindische Kompanien (1661-1792), Triest-Antwerpen, Kart. 1: Ostindische Kompanie Triest Antwerpen 1661, 1766-1789, Fasz. 1, Fol. 38-41.

48 „Rapport Touchant les raisons qui ont oblige Bolts a changer les vries, qu'il avoit sur Lisbonne et les desirs de son associe Francois Ryan", HHStA, Ostindische Kompanien (1661-1792), Triest-Antwerpen, Kart. 1: Ostindische Kompanie Triest Antwerpen 1661, 1766-1789, Fasz. 1, Fol. 26-31.

${ }^{49}$ Adam von Lebzeltern was an Austrian ambassador to Lisbon practically for 50 years, 1768-1818.
} 
Bolts' logistics network during these months involved intensive communication between London, Lisbon and Livorno. In September 1775 Bolts bought East Indian "Earl of Lincoln" in London, a ship that had previously belonged to the British East India Company and which had already been well tested during the travels to India. ${ }^{50}$ In honour to the Austrian rulers, after the purchase of the ship Bolts changed her name to "Joseph and Theresa." It was to serve as a further demonstration of his loyalty to the Austrian dynasty, but also to send a message to all rivals that Austria stood firm behind all of his undertakings.

After that, with a ship that still carried the British flag and which was largely manned by British crew, Bolts headed for Lisbon. However, during the spring of 1776, the protagonists of the future Austrian Indian expedition remained in Portugal unexpectedly long due to a number of administrative problems. Basically that was a sophisticated action directed against Bolts from London, which was already a consequence of the actions of the British East India Company, i.e. Great Britain itself against unwanted Austrian competition, whereby Britain could count on its traditional alliances with Portugal. After many peripherals and an energetic action by the Austrian ambassador, Bolts could continue his journey to Livorno, where he would perform the main loading of goods for trade. Lebzeltern's comprehensive report on all events was sent to Vienna on 4 June $1776 .{ }^{51}$ At the end of June Bolts finally arrived in Livorno, but the British ensured that his secret trade mission no longer had a tag of secrecy, which was reflected in numerous news about the expedition in the European newspapers of that time even before he took off on the trip.

After the rifles and cannons were embarked on the ship in Livorno, which were to be the key Austrian export items, and after further complicating of relations between Bolts and Proli, Bolts headed to India in late September 1776 with a crew of 152 sailors. ${ }^{52}$ In this way, the new Austrian Indian odyssey began and, as will be shown later, would last for five years in its first incarnation.

Although the whole complex of reanimation of the Austrian Asian trade was actually liquidated at the end of the $18^{\text {th }}$ century in the turbulences of the French Revolutionary Wars, and during the $19^{\text {th }}$ century it was never restarted in the way it was accomplished in the 1770s, an episode about a company founded by William Bolts (or two consecutive companies) left a big mark on the systematic development of the Austrian approach to various aspects of world politics. An attempt to encourage trade with India, and during the 1780s with China, Japan and the Pacific and north western North America, gave Austria a new dimension which Vienna actually greatly desired during the greater part of the $18^{\text {th }}$ century and made it less provincial in the increasingly dominant context of European powers at the planetary level. The fact that perspectives from the 1770s and 1780s did not ultimately lead to a permanent transformation of Austria into a trade and maritime power - was linked

\footnotetext{
${ }^{50}$ HHStA, Ostindische Kompanien (1661-1792), Triest-Antwerpen, Kart. 4: Diplomatische Korrespondenz der Staatskanzlei mit der Kompanie (1774-1786), Fasz. Diplomatische Korrespondenzen der Staatskanzlei 17741776, Konv. Ostindische Compagnie Correspondenz mit auswärtigen Höfen und Gubernien 1775, Fol. 62.

51 HHStA, Ostindische Kompanien (1661-1792), Triest-Antwerpen, Kart. 3: Ostindische Kompanie Triest Antwerpen (1774-1788), Fasz. Korrespondenz der Staatskanzlei mit Hofstellen 1774-1776, 1778-80, Konv. 1 (1-2), Fol. 56.

${ }^{52}$ HHStA, Ostindische Kompanien (1661-1792), Triest-Antwerpen, Kart. 6: Korrespondenz der Staatskanzlei mit der Kompanie (1782-1788), Fasz. 1776-1785, Miscellanea.
} 
to a series of structural weaknesses that the country carried and additionally accumulated in continuity that lasted already for a few centuries.

An example of the "engagement" of William Bolts was an indicator of the maturation of Austrian diplomacy in the second half of the $18^{\text {th }}$ century and its instant modernization, which developed especially after 1763. The Austrian diplomatic network with its wider connections was in a position to follow political and economic trends much more efficiently. However, for example, its inability in 1775 or 1776 to perceive the development of a geopolitical constellation over the next few years, i.e. to see that, due to the rebellion of the British colonies in North America a major war for the dominance in the North Atlantic would over the years engage both Britain and France and at the same time paralyze their efforts elsewhere, which left enormous opportunities in terms of exploiting Asian trade to neutral states such as Austria - was a testimony that some aspects of Austrian modernization were still far from ideal.

\section{REFERENCES:}

Österreichisches Staatsarchiv, Abteilung Haus-, Hof- und Staatsarchiv, Ostindische Kompanien (1661-1792), Triest-Antwerpen:

-Kart. 1: Ostindische Kompanie Triest Antwerpen 1661, 1766-1789

-Kart. 2: Ostindische Kompanie Triest Antwerpen (1774-1787)

-Kart. 3: Ostindische Kompanie Triest Antwerpen (1774-1788)

-Kart. 4: Diplomatische Korrespondenz der Staatskanzlei mit der Kompanie (1774-1786)

-Kart. 6: Korrespondenz der Staatskanzlei mit der Kompanie (1782-1788)

„The Gentleman's Magazine“, 1785, ii., 920.

Aretin, K. O. Freiherr von, 'Fürst Kaunitz und die österreichisch-ostindische Handelskompagnie von 1775: Prof. Johann Albert Frhr. v. Reiswitz zum 60. Geburtstag. Ein Beitrag zur Geschichte des österreichischen Staatsbewußtseins unter Kaiser Joseph II', Vierteljahrschrift für Sozial- und Wirtschaftsgeschichte, 46. Bd., H. 3 (Oktober), 1959, 361-377.

Baguet, J. 'Politics and commerce: a close marriage? The case of the Ostend Company (1722-1731)'. Tijdschrift voor Sociale en Economische Geschiedenis, 12 (3), 2015, 51-76.

Beer, A. „Die österreichische Handelspolitik unter Maria Theresia und Josef II.“, Archiv für österreichische Geschichte, 86, 1899, 1-204.

Bolts, G. Recueil de pièces Authentiques, relatives aux affaires de la ci-devant Imperial asiatique Société de Trieste, gérées à Anvers, 1787.

Bronza, B. 'Austrian Diplomats from the Vienna Oriental Academy on the Balkan Peninsula During the Second Half of the Eighteenth Century', in Maria Baramova, Plamen Mitev, Ivan Parvev, Vania Racheva (Eds.), Power and Influence in South-Eastern Europe, 16th-19th century, Berlin, 2013, 329-338.

Eberstein, B. Preußen und China. Eine Geschichte schwieriger Beziehungen, Berlin: Duncker \& Humblot, 2007.

Erceg, I. 'Der Merkantilismus in Kroatien. Die Handelspolitik des Habsburgerstaates im 18. Jahrhundert mit besonderer Berücksichtigung Ungarns und seiner Nachbarländer', Österreichische Osthefte, 8, 1966, 300-308. 
Faber, E. Litorale Austriaco. Das österreichische und kroatische Küstenland 1700-1780, Schriftenreihe des Historischen Instituts, Nr. 5, Veröffentllichungen des Steiermärkisches Landesarchives 20, Trondheim-Graz, 1995.

Frendo, H. 'The French in Malta 1798 - 1800: reflections on an insurrection', Cahiers de la Méditerranée, 57, 1998, 143-151.

Gasser, P. 'Österreichs Levantehandel über Triest 1740-1790', Mitteilungen des Österreichischen Staatsarchivs, 7, 1954, 120-130.

Gough, B. M. and Robert J. King, 'William Bolts: An Eighteenth Century Merchant Adventurer', Archives: the Journal of the British Records Association, vol. XXXI no. 112, 2005, 8-28.

Hallward, N. L. William Bolts, A Dutch Adventurer under John Company, Cambridge: Cambridge University Press, 1920.

Houtman-De Smedt, H. Charles Proli. Antwerps Zakenman en Bankier, 1723-1786. Een Biografische en Bedrijfshistorische Studie, Verhandelingen van de Koninklijke Academie voor Wetenschappen, Letteren en Schone Kunsten van België. Klasse der letteren 45, no. 180, Brussel, 1983.

. 'The ambitions of the Austrian Empire with reference to East India during the last quarter of the eighteenth century', in Sushil Chaudhury, Michel Morineau (Eds.), Merchants, companies and trade. Europe and Asia in the early modern era, Cambridge: Cambridge University Press, 1999, 227-239.

Israel, J. The Dutch Republic: Its Rise, Greatness, and Fall 1477-1806, Oxford: Clarendon Press, 1995.

Keay, J. The Honourable Company. A History of the English East India Company, London: Macmillan, 1991.

Markov, W. 'La Compagnia Asiatica di Trieste', Studi Storici, 2 (1), 1961, 3-28.

Michielsen, L. „Het einde van de Oostendsche Kompagnie“, Bijdragen tot de Geschiedenis, 28, 1937, 121-134.

Nagel, J. G. Abenteuer Fernhandel. Die Ostindienkompanien, Darmstadt: Wissenschaftliche Buchgesellschaft, 2007.

Pollack-Parnau, F. von, 'Eine österreich-ostindische Handelskompanie, 1775-1785: Beitrag zur österreichisch Wirtschaftsgeschichte unter Maria Theresia und Joseph II', Vierteljahrsschrift für Sozial- und Wirtschaftsgeschichte, Beiheft 12, Stuttgart, 1927.

Temple, Sir R. C. 'Austria's Commercial Venture in India in the Eighteenth Century', Indian Antiquary. A Journal of Oriental Research, XLVI, 1917, 277-286.

Williams, R. London's Lost Global Giant: In Search of the East India Company, London: Bristol Book Publishing, 2015. 


\section{БОРО БРОНЗА}

Универзитет у Бања Луци

Филозофски факултет

\section{ПРИПРЕМЕ АУСТРИЈСКЕ ЕКСПЕДИЦИЈЕ ПРЕМА ИНДИЈИ 1775-1776}

\section{Резиме}

Током друге половине XVIII вијека трговачка политика Аустрије је настојала да обнови везе са Индијом и другим крајевима Азије које су успјешно егзистирале у доба Остендске компаније (1722-1731). У том погледу је све успјешније дјеловање Британске Источноиндијске компаније представљало примјер за бечку владу какве лукративне могућности леже у адекватном развоју трговине на истоку. Неопходна карика за покретање таквих подухвата била је могућност директног сусрета представника аустријске дипломатске мреже са појединцима из реда трговаца који су већ имали богата искуства у оквирима трговине са Индијом. Управо такав случај се догодио у Лондону 1774. године када је аустријски амбасадор Лудовик Луиђи Карло Марија ди Барбиано ди Белгијосо (Ludovico Luigi Carlo Maria di Barbiano di Belgiojoso) сусрео једног од најпознатијих европских предузетника друге половине XVIII вијека Вилијама Болтса (Williama Boltsa). Био је то почетак нове велике аустријске авантуре у Азији и истовремено покушај радикалног редефинисања есенцијалне природе хабзбуршке позиције и философије. Непосредно након што је аустријска дипломатска мрежа ступила у контакт са Болтсом, почеле су софистициране припреме експедиције која ће на свој пут коначно кренути 1776. године.

Иако је цијели комплекс реанимирања аустријске азијске трговине фактички ликвидиран већ крајем XVIII у турбуленцијама Француских револуционих ратова, те током XIX вијека никад није поново покрену на начин како је то било реализовано 1770-их година, епизода око компаније коју је основао Вилијам Болтс (односно двије узастопне компаније) оставила је велики траг у системском развоју аустријског приступа различитим аспектима свјетске политике. Покушај потицања трговине са Индијом, а током 1780-их година и са Кином, Јапаном и простором Пацифика и сјеверозападне обале Сјеверне Америке, дао је Аустрији нову димензију која јој је веома недостајала током већег дијела XVIII вијека, те ју је учинио мање провинцијалном у све експанзивнијим европским оквирима.

Примјер око „ангажмана“ Вилијама Болтса био је индикатор сазријевања аустријске дипломатије у другој половини XVIII вијека, односно њене инстантне модернизације, која се развијала нарочито после 1763. године. Аустријска дипломатска мрежа била је у позицији да својим везама прати све више политичких и економских трендова. Ипак, њена немогућност да нпр. 1775. или 1776. године проникне у развој геополитичке констелације у периоду од наредних неколико година, односно да увиди да ће због побуне британских колонија у Сјеверној Америци доћи до великог рата који ће Британију и Француску током неколико година превасходно везати за простор сјеверног Атлантика што је неутралним државама попут Аустрије остављало огромне могућности на плану експлоатације азијске трговине - била је свједочанство о томе да су наведени аспекти њене модернизације још увек били далеко од идеалног.

Кључне ријечи: Аустрија, Индија, Марија Терезија, Јосип II, Вилијам Болтс. 